\title{
Imperial Capitals at War: A Comparative Perspective
}

\author{
Adrian Gregory
}

The First World War created serious challenges to the resilience of the population of the great imperial capitals of the major combatants. The effectiveness in responding to these challenges would play an important role in determining the outcome of the war itself. London was the mightiest of all the imperial capitals, overmatching the others in wealth and population just as the Empire that it ruled was the pre-eminent one. But understanding some of the commonalities of the challenges which it shared with other great capitals can help us understand the ways in which London responded to the upheaval of war.

The concept of specifically 'imperial capitals' helps to capture two particular dimensions which London shared with only a very small group of urban centres during the war. The comparable imperial capitals were St Petersburg (which was renamed Petrograd at the outbreak of the war in a fit of nationalism, although most of its inhabitants continued to use the old name, a precedent I am largely going to follow), Paris, Berlin, Vienna and Constantinople. They were large cities but it was not just a matter of size. These imperial capitals tended to be more complex than other cities in their social and cultural identity. They had an outward facing aspect that made them important both throughout and beyond their own Empires. Equally significantly, they were the key centres of political power and as a result were central to the narrative of the war from the pre-war July crisis onwards. During the diplomatic overture to war the words 'Paris', 'Berlin', Vienna', 'London', 'St Petersburg' became shorthand for the principle governmental actors. 'Constantinople' would serve the same function for the Ottoman Empire two months later. Even the mightiest alternative urban centres Manchester, Munich, Budapest or even Moscow were to a large extent provincialized by the big six from the outbreak of war. This also rendered the capitals significant targets for strategic pressure.

Other combatant capitals were not really comparable. Brussels had recently become an imperial capital and was acquiring the architecture to match, but was much smaller in population. Lisbon, the capital of the oldest European empire, was a rather marginal combatant. Likewise Tokyo, the capital of the new/old Japanese Empire. Washington DC was less marginal in some respects but peculiar in other ways; Bucharest and Belgrade which shared with Brussels the experience of wartime occupation were small and not imperial, and so were Sofia and Athens. The case of Rome is the closest, another new/old imperial city. But Rome was very peculiar, the presence of the 'captive' Papacy, the economic marginality of the place and above all the fact that it was still a relatively small city, exceeded in population size in 1914 even within the Kingdom of Italy by both Milan and Naples.

The paired and opposed triads of Paris, London and St Petersburg alongside and against Berlin, Vienna and Constantinople by contrast had clear similarities with each other. Each was a city of fundamental political significance. All of them except Paris were intimately connected with long established ruling dynasties and Paris was equally fundamental in the legitimacy of the French Republic. St Petersburg, the relative newcomer, could still look to 200 years as the dynastic capital.

Each was the seat of an 'imperial government'. True, this was complicated in the case of Vienna by the presence of a theoretically equal capital for the Dual Monarchy in Budapest but the regular presence of the König/Kaiser and the Imperial Cabinet in Vienna made it clear which capital could claim primacy. For the other cities the presence of an 'imperial' legislature - which was very new in the cases of St Petersburg and Constantinople was important to their wartime roles. Whilst the British Empire had several other sovereign legislatures by 1914, all of them to a certain extent deferred to Westminster in 'Imperial matters', not least in the decision to declare war, just as the still significant state legislatures in German Reich did to the Reichstag.

These cities also had a central role in popular politics within their empires. Constantinople had 
seen the political upheavals of the 'Young Turk' movement and St Petersburg was the epicentre of the 1905 revolution. London had seen an intense battle for control between a progressive alliance and a 'economy' minded 'reform' movement, Paris and Berlin were major centres of socialism in their respective countries, and the volatile politics of Vienna had given rise to the first truly modern antiSemitic party.

In terms of population, all of them were above the threshold of high significance for a modern metropolis. All had populations significantly above one million. London with a population in excess of seven million was of course in a class of its own, the greatest city on the planet with only New York anywhere close in 1914. But Paris and increasingly Berlin were making the transition from metropolis to megalopolis with just over four million and just under four million in the greater urban area of each. Vienna and St Petersburg were each greater than two million and Constantinople somewhat over a million. Five of the cities were comfortably the largest within their empires; St Petersburg was the exception with the old capital Moscow a similar size. None of them could be fed solely by the produce of their immediate hinterland. All were to some extent centres of commerce, all were to some extent centres of industry, perhaps a bit less so in the case of Vienna and particularly Constantinople. Berlin in particular was by 1914 was developing a reputation as an important manufacturing centre for the cutting edge electrical industry. All of the cities contained important garrisons and were the site of war ministries.

These cities also had genuine international cultural significance. Paris had been the first 'capital of cultural modernity' and was still generating significant innovation in the first decade of the twentieth century. Pre-war Vienna is now recognized as one of the most important artistic and intellectual environments that has ever existed. St Petersburg began to undergo an important florescence a little later and Berlin, although challenged by Munich for primacy in Imperial Germany was following suit. Constantinople was the home of a multi-ethnic intelligentsia in the late Ottoman period. Pre-war London might in some respects look less dramatic, but there were significant trends in art and literature which would come to a fuller fruition in the interwar period, in that respect at least London was not unlike Berlin.

In attempting to understand the challenge that war would present to all of these cities it is useful to think in terms of the classic understanding of siege warfare. The fundamentals of siege warfare are bombardment, assault, blockade to impose starvation and the hope of encouraging internal revolt against the city's leadership. The image that a siege usually brings to mind is something medieval, but this would be to overlook the importance of sieges in modern industrial warfare. The two prototype industrial wars, the American Civil War and the Franco-Prussian war climaxed with the sieges of capital cities. In the former, the Confederate capital of Richmond was the ultimate objective of the main Union campaign and in the latter the siege of Paris represented the largest and decisive operation. Looking toward the Second World War, the siege motive recurs. Terrible as the suffering of other British cities was at times, the Blitz was at its heart a sustained and prolonged bombardment of the capital. Barbarossa climaxed with a failed assault on Moscow (and the horrific starvation blockade of the former capital, now Leningrad). The European war ended with an apocalyptic assault on Berlin, the capital of the Reich and outside Europe the Japanese capital had been burned to ashes. The experiences of the First World War were not this extreme, but the war against the capital cities was a central part of combatants' strategy. The rest of this essay will consider the four dimensions of siege in regard to each of the six capitals in as far as they apply.

Paris was the fulcrum of military operations in the autumn of 1914. As the centre of the French railway network as well as the seat of government it was the ultimate objective of the great German offensive at the start of the war. French defeat in the 'Battle of the Frontiers' meant that the Paris military district took on a crucial significance at the end of August. The commanding presence of the great hero of French colonial campaigns, General Gallieni, helped steady the nerves of the population 
at least to some extent. But only to some extent. Refugees flooding into the city, fleeing from the advancing Germans, were matched by a flight of bourgeois residents from the city who wished to avoid being caught in a trap. Memories of 1870, both of the German siege and the subsequent Commune meant that those with the means to escape did so. The temporary evacuation of the government to Bordeaux did little to calm nerves and the first air raids of the war helped emphasize the proximity of the enemy. So did a programme of demolition in the suburbs as the perimeter defensive zone was activated and fortifications were readied for use. Paris was the unavoidable transfer point for the armies rushing westward to block the German offensive, troop from the east of France were redeployed through the Gare De L'Est and then moved onwards. Although the 'Taxis of the Marne' did not in themselves decide the outcome of the battle, the evocative image of the urban transport packed with infantry being driven almost to the battlefield became part of the abiding memory of 1914. London made its own rather less immediate contribution in this respect with the BEF commandeering some buses. ${ }^{1}$ The first battle of the Marne bought the French capital some breathing space, but in a broader sense Paris remained the central focus of the Western Front for most of the war. The Noyon salient, the great bulge of the Western Front, represented a standing strategic threat to the French capital and offensives at the base of the salient in Artois and Champagne in 1915 and at the centre of the salient on the Somme in 1916 were launched to a large extent to remove this immediate threat to the capital. The German retreat in spring 1917 added a bit more of a glacis but the great German offensive of spring 1918 resurrected the threat (and the flight of wealthier civilians). Although the immediate sense of emergency was most acute in 1914 and 1918 Paris never lost the feel of a city close to the front line. The presence of soldiers on leave and the wounded was a constant.

London, despite the flurry of invasion scares in 1914, never faced the prospect of direct assault, nor did Vienna or Berlin, although all the cities would end up accommodating large populations of refugees from the early campaigns. St Petersburg began the war very distant from military operations but as the German armies advanced through the Baltic it was gradually drawn closer to the zone of the conflict. The German conquest of Riga in September 1917 and subsequent amphibious operations brought the threat of attack uncomfortably close. ${ }^{2}$ After the Bolshevik revolution the new revolutionary government was made painfully aware of the proximity of German forces when the negotiations at Brest-Litovsk broke down. It was the resumption of the German advance which discredited Trotsky's novel 'no war, no peace' initiative and forced the new government to accept German demands.

Alongside Paris, the capital which most directly faced the prospect of direct assault was Constantinople, albeit that the threat to the Ottoman capital was more from naval and amphibious forces than from massed armies. Anglo-French naval forces threatened the Dardanelles from the start of the war and made a major effort to breach the straits on 18 March 1915. This was followed by an assault on the Gallipoli peninsula by a combined expeditionary force from 25 April 1915. From the Ottoman point of view that battle was fought on the main line of defence for the capital and Constantinople was the rear base of operations. Just as Paris had used taxis to transport soldiers to the front (although the actual numbers moved in taxis were probably small), Constantinople's city ferries were pressed into service to shuttle soldiers and ammunition to the peninsular and to bring back the wounded. Like the first battle of the Marne, Gallipoli was a defensive success that held the enemy back from the capital and allowed the war to continue, the attackers were finally evacuated in January 1916.

At the very end of the war the breakthrough of the allied army at Salonika resumed the threat to Constantinople at a time when there were few Turkish troops left to protect the capital, it also more distantly posed a potential threat to Vienna. Yet in the end none of the major imperial capitals fell to assault whilst the war continued, and Constantinople only experienced occupation after the Armistice of Mudros. The peculiar technological mix of the war including railways, rapid firing artillery, the telegraph and barbed wire had made the 'distant' defence of capitals highly effective.

One new piece of technology represented a potential means of overcoming or at least evading this enhanced defence. The new menace was aircraft. The threat of bombardment had been an element 
of sieges even before the invention of gunpowder but aircraft significantly extended the range of this threat. Even before the war the prospect of air attack had captured the imagination of science fiction writers. ${ }^{3}$ Heavier-than-air craft had dropped bombs for the first time in Libya in 1911, but at the start of the war the serious possibilities of bombing were much more obvious for airships. Although Paris was raided by German aircraft in 1914 the serious start of strategic bombing was Zeppelin raids on the city from March 1915. But from the end of May 1915 the principle focus of German strategic bombing would shift to London where it would remain for much of the next three years. The story of this 'First Blitz' is too well known to require repeating here. ${ }^{4}$ To some extent it is the story of a successful albeit costly defence which in turn defeated the Zeppelins and then the Gothas, the new generation of German bombing aircraft from 1917. The last and largest air raid of the war on London occurred on 19 May 1918 when six Gotha bombers were shot down by the city's extensive air defences. Whilst bombing undoubtedly brought distress to much of the population and drove some to leave the city or to camp out in the underground stations but it can also be argued that the experience of being bombed also gave Londoners a sense of being active combatants in the war which to an extent boosted their morale. Whilst the post-war analysis often put the main emphasis on the rare occasions of civilian panic, often in a very racially inflected way, there were also many indications of an early version of what would later be romanticized as the 'Blitz spirit'.

Paris would be intermittently bombed throughout the war but serious bombing resumed in early spring 1918 as the German Gotha bombers began to shift their attention away from London to supporting the renewed German offensive in France. At the very end of the war, in response to the Gotha raids, the French authorities began constructing a decoy replica city 15 kilometers away at Maisons Lafitte, complete with replica landmarks such as the Eiffel Tower, Opera and Gare du Nord. It was not completed by the time of the last raids and its existence was subsequently kept secret until the early twenty first century. Such precautions might have proved justified, since at the end of the war the Germans were planning renewed attacks on both Paris and London with thousands of the new onekilogram 'Elektron' incendiary bomb with the hope of starting apocalyptic fires. ${ }^{6}$

Constantinople was the other capital to experience air attack, although on a far smaller scale. British seaplanes attacked the city in 1915 and 1917. Russian aircraft also attacked the city, a raid in August 1915 killing 30 Turks, eight Greeks and three Armenians according to contemporary newspapers. In autumn 1917 an intermittent strategic offensive began against the city, and the future pioneer transatlantic flier John Alcock was captured by the Turks when his plane was forced to ditch in September 1917. On 18 October that year 54 Ottoman civilians died in a raid aimed at a military target but which instead hit a Mosque. Like London and Paris, Constantinople was forced to develop an air defence system, a joint German-Turkish effort of fighter aircraft and anti-aircraft guns that operated until the end of the war. ${ }^{7}$

Towards the end of the war Vienna could feel for the first time the shadow of the bomber. The spectacular transalpine flight in August 1918 led by the poet aviator Gabriele D'Annunzio had deliberately dropped leaflets rather than bombs. The leaflets had clearly indicated that bombs might follow if the war was to continue, but given that they were written in somewhat florid Italian and not translated into German the message may have been missed. ${ }^{8}$ Berlin was similarly spared by the end of the war, although the RAF was in the process of commissioning its first 'Berlin bombers', planes like the Handley Page V1500 with sufficient range to reach the German capital from airbases in East Anglia. The first Berlin mission was in fact scheduled for November 1918 but was cancelled due to the Armistice talks.

Paris was the only city to suffer long range artillery bombardment during the war. The immense 'Paris gun' (actually guns) located in the forest of Couchy, more than 100 kilometers from the city, opened fire to coincide with the German 21 March offensive. At its peak it was firing a 106 kilograms shell into the city every 20 minutes. The supersonic velocity of the shells meant that they struck without warning. The most devastating effect was when a shell struck the church of St Gervase in the middle of 
the Good Friday service. The explosion killed 77 and wounded more than 100. In all the bombardment, which continued until the summer, caused more than 800 casualties, more than 250 of them fatal. ${ }^{9}$ Relative to size Paris suffered similar casualties to London and a roughly similar duration of bombardment. But London still deserves to be considered the city which was most systematically subject to strategic bombardment during the war in that the attacks on Paris in 1918 were much more supplementary to German operations on the ground.

Bombardment in the First World War was undoubtedly a less lethal threat than starvation. The biggest threats to besieged cities throughout history have been the linked terrors of hunger and disease. The deliberate use of blockade as a weapon of war, as well as the disruptions to supply of the hinterland and the complicated balancing of civilian and military supply made the question of civilian provisioning one of the key battlefields of the entire conflict. The first city to be reduced to a critical level of shortage was St Petersburg. This was not directly attributable to German blockade, although the sudden influx of 300,000 refugees fleeing German armies in the course of 1915-1916 rendered the provisioning (and housing) problem more acute. The central issue was the developing breakdown in the Russian Empire's own capacity to move food to where it was needed. Until the spring of 1915 there was no attempt to interfere with the operation of the free market. At this point shortages and inflation saw the Petrograd Duma set up a Municipal Supply Commission to deal with developing shortages of meat (the city had no refrigeration stores and was reliant on livestock imports). ${ }^{10}$

Despite the best efforts of the city government to purchase as far afield as the Volga, the supply situation deteriorated over the course of the next year. Rationing was discussed and rejected in December 1915 on the grounds that it was likely to fail and in failing generate anger against the authorities. The authorities also underestimated the level of demand by failing to account for the refugee population. But in the end the administration was crippled by the wider situation, and even the underestimated requirement of 12,000 wagon loads of food per month was only met twice in the course of 1916. The basic problem was that the Russian railways were heading towards collapse: the demands of supply to the front were starving the civilian network of resources, coal was not being supplied in sufficient quantities, rolling stock and engines were wearing out and not being replaced. The prioritization of arms production, whilst providing work for the St Petersburg population, was at the same time depriving them of necessities as the military industrial complex sucked in most of the fuel and transport. Gradually everything ran out. Tea, sugar, salt and fats were already in short and intermittent supply by the end of 1915. By the end of 1916 meat, ham, eggs and fish had vanished from the markets. Even more crucially the supplies of potatoes and rye flour started to run out in January 1917. The black market allowed some of the richest access to necessities and even luxuries but by early 1917 even the bulk of the middle classes could no longer manage as not only food but soap and boots disappeared from the shops. The political result is well known; the shortages and subsequent inflation fuelled strikes and protests which led in turn to the great walkout of March (old calendar February) 1917. It was a protest about bread shortages amongst the female textile workers of Vyborg. It is in fact possible that the bread shortage was not due to empty granaries - there may in fact have still been a meagre two week supply of rye flour - but due to panic buying caused by the rumour of the implementation of rationing and by misallocation. Whatever the reason, the protests on International Women's Day which began with attacks on food shops quickly escalated over the next few days with the slogan changing from 'Give us bread' to 'Down with the Government'. Within four days the Petrograd garrison had defected to the side of the protestors and the Tsarist regime collapsed. ${ }^{11}$

Events in St Petersburg in March 1917 demonstrated the political potential of hunger well enough to give a sharp sense of concern to the municipal and higher authorities in Vienna and Berlin. Vienna was subject to the pressures of blockade but as in the case of St Petersburg this was secondary to other factors in the breakdown of urban food supplies. With very few exceptions pre-war Vienna had obtained its food from within the Empire. But the outbreak of war had turned one of the city's main granaries, Austrian Galicia, into an inaccessible battlefield. The recapture of much of the region in 
summer of 1915 was partially reversed in the summer of 1916 by a new Russian offensive. Even when the Russian army was finally driven out in 1917 the devastated farms of the region were a shadow of their former selves. To add to the misery significant numbers of the region's population, particularly Jews who had been persecuted by the invaders, had fled to the Austrian capital. Traditionally the great reserve of agricultural production was the Hungarian half of the Dual Monarchy, which prior to the war had already provided most of the meat and about a quarter of the grain to Vienna, but the wartime Hungarian government proved uncooperative in provisioning the Austrian half of the Empire. The Hungarians became an important target for the hatred of the metropolitan population although they responded, with some justification, that the burden of supplying the Imperial armies in the field had fallen almost entirely on their half of the Empire. Next to the Hungarians, the other target of the city dwellers' wrath was profiteering farmers from the immediate hinterland who were alleged to be making massive profits from the black market. ${ }^{12}$

Whatever the principle causes, the shortages mounted throughout the war to ultimately devastating proportions. Bread first ran short in autumn 1914, milk and potatoes in the spring of 1915, coffee, sugar and eggs in spring 1916 and pretty much everything else by the autumn of that year. By 1917 the queue had become ubiquitous and on a single day 783 lines had formed, comprising perhaps 250,000 people or more than $10 \%$ of the city's population. Rationing of bread began in spring 1915 and fats, sugar, milk and coffee in 1916. Perhaps surprisingly, meat rationing did not occur until 1918 but when it did the ration was a tiny 28 grams. Once rationing began the rations were regularly cut and by the end of the war the Viennese adult not involved in 'heavy labour' was nominally entitled to rations that amounted to 830 calories per day, a figure well below the minimum required to sustain health in a central European winter. What was worse is that this nominal ration was increasingly unobtainable in practice. $^{13}$

The picture for Vienna is unambiguous: by the end of the war the city was starving. In the last year of peace the annual death toll of women in the city was 15,310 , but by 1918 this had risen to 23,898. Not all of this excess mortality could be attributed to malnutrition; the Spanish influenza was cutting a swathe globally through the well-nourished and starving alike. But Viennese doctors believed that somewhere between 7 and $11 \%$ of all wartime deaths were directly caused by starvation and a further 20-30\% saw malnutrition as a contributing factor. Total civilian mortality from starvation may have exceeded 50,000. ${ }^{14}$ As in St Petersburg, urban authorities and voluntary organizations tried to tackle the crisis and were similarly overwhelmed. One irate citizen sent their useless fat ration cards to the Mayor in 1916 with the instruction that he burn them and shove them up his arse. A mother wrote from Weiskirchner in 1917 that if thigs did not improve she would be forced to abandon her children as wards of the city. The Mayor was accused of being in league with 'Jewish profiteers'. But in even greater numbers the population turned on each other in a stream of denunciations of profiteers and hoarding. Profiteering was certainly real: in an average week in 1917 more than 300 people were charged with violating the price ordinances. In response to public anger a 'pillory list' was instituted in February 1917 with the names of profiteers publicly posted in their home districts. But even this didn't appease popular anger; an insufficiency of Jewish names led to allegations that the 'big fish' were being let off whilst the small fry were humiliated.

The Viennese legal theorist Josef Redlich would conclude that the shortages had driven Vienna to a state of 'social decomposition'. Social relations had degenerated into rudeness, dishonesty, envy and even violence. In 1918 urban dwellers increasingly took matters into their own hands, raiding farms around the city and fighting in food queues. People would not give up places in line to the disabled or the elderly. One woman who tried to take her place in front of a butchers shop at 5pm in May 1917 was driven away by stone throwing children for being too early. Attempts by the authorities to enforce priority for pregnant women were met with hostility. Food riots in Vienna did take on a political aspect, and calls for peace were part of the vocabulary of rioters by 1916. By January 1918 food protests and strikes began to merge together, climaxing in peace demonstrations more than 500,000 strong. But in 
the end the Viennese did not go down the revolutionary road until the army had completely collapsed in the field in October 1918 and the empire had begun to disintegrate on ethnic lines. Indeed years of almost Hobbesian struggle for survival may have in some respects undermined the capability for prolonged solidaristic protest.

Berlin under 'blockade' was at the time and remains a contentious case. Germany unlike Russia and the Habsburg Empire was a significant net importer of food; $20 \%$ of all calories consumed came from beyond its borders, including $27 \%$ of all protein and $42 \%$ of fats. In this sense it was much already more vulnerable to wartime blockade although perhaps less so than German cities further to the west. Furthermore and perhaps ultimately more significantly the Entente blockade had a severe effect on the productivity of German agriculture. Germany had maintained a high level of agrarian productivity through the import of fertilizer, and the cutting off of supplies was seriously detrimental to output. Combined with the loss of draft horses and manpower to the army, German agricultural output fell severely. There can be no doubt that the supply of food available to Berlin fell but there is a lot more debate as to whether the food that remained was sensibly managed. Some historians point the infamous Schweinemord of 1915 as exemplary of poorly conceived food policy. The imperial government sought to save grain by ordering a mass slaughter of pigs. Nominally sensible given the wasteful calorific conversion involved in feeding cereals to animals, the result was a sudden wasteful glut of pork products followed by a severe shortage which incentivized the black market for the rest of the war. The black market certainly became a crucial element in the Berlin food supply before the end of 1915 and by 1917 some degree of 'off ration' purchasing may have become a prerequisite of avoiding malnutrition. Nevertheless some historians take the view that the civic management of supply in Germany was about as good as can be expected given the real nature of the shortages. ${ }^{15}$

The consequences for the population of Berlin in terms of whether the shortages amounted to starvation are equally controversial. There are some indicators of severe problems. In 1917 the death rate of the elderly in Berlin spiked alarmingly: the number of over sixties dying exceeded 15,000 compared to just below 10,000 in $1914 .{ }^{16}$ It is likely that the combination of food shortage and coal shortage interacted to produce this outcome, which was not mirrored in Paris or London. In all the excess death toll for Berlin from malnutrition during the war might approach 30,000, almost certainly lower than Vienna from a population of nearly double the size. But as in Vienna the impact of the blockade should not only be measured in the physical consequences of higher mortality and the stunted growth of children. Just as in Vienna the ubiquity of the black market and the increasing signs of social breakdown damaged, perhaps permanently the trust between citizens and faith in the law and the state.

There is less readily available historical literature on food supply in Constantinople, but paradoxically it may be a unique case where metropolitan conditions were actually less desperate than some of the agrarian conditions in much of the Empire. Much of Anatolia and most of the Levant descended into outright famine during the war but the least war-affected parts of the Empire were in the immediate vicinity of Constantinople. ${ }^{17}$ But less desperate does not mean good: wartime measures of Turkification against the Armenian and Greek merchant classes were in certain respects an outright licence to profiteer as individual connections with the CUP government could be exploited at the expense of the public. ${ }^{18}$ Furthermore some of the traditional supply routes of Black Sea grain to the city were badly disrupted. The price of basics inflated accordingly: by one account the price of potatoes in January 1918 had reached a level 30 times greater than the summer of 1914. It is suggested that the food supply situation in the last years of the war might have been at least as bad as Petrograd and that inflation was comparable. The wartime journal of Mrs Mary Lyster notes that in February 1916 a loaf of bread had cost six piastres, but in May 1917 it cost 23 piastres. In September 1917 she noted the joyful news that the ration of bread had been increased by 110 grams - although at an increase in cost. $^{19}$

London and Paris suffered shortages but the degree of privation never reached that of the other major capitals. Memories of 1870 and the political significance of bread in particular made food supply 
a sensitive issue in Paris. For the first three years of the war the food supply, assisted in the case of bread by government subsidy, held up remarkably well. Meat shortages were countered by the purchasing of frozen meat from abroad. Sugar rationing came early in 1917 but even into the spring of that year patisserie was still being produced. ${ }^{20}$ In Paris bread rationing was introduced by degrees between the summer of 1917 and full rationing in March 1918. The price of bread remained tightly controlled although the shift from white flour to whole wheat was generally disliked. 1917-1918 saw a severe new bout of inflation for most other products and a shift in consumption towards substitutes including a significant rise in horse butchery. Prices doubled between the autumn of 1917 and the autumn of 1918. But overall it is probably the case that Paris during the war remained the best fed of the capital cities, a tribute to good city management, the massive efforts of the mostly female French agricultural workforce and, by 1918, some good shipping and food import management. London also managed comparatively well and was able to avoid formal bread rationing even at the height of the German U-Boat campaign. London did suffer serious shortages in the second half of 1917 and by the end of the year the problem of food queues for sugar, meat and margarine had become fairly severe. Nevertheless neither the queues nor the black market ever approach the level of the situation in Vienna or Berlin. ${ }^{21}$

Traditionally the collapse of morale and internal betrayal has been the coda of many sieges and fear of such an outcome was hard wired in the European elites. The expectation that the literally degenerate urban mob would succumb to desperation and revolution in response to the mounting misery of war was a staple of the strategic thinking of the era. Ethnically mixed populations prone to the siren call of socialism were seen as lacking the solid patriotic virtue of the peasantry. The hopes of the left and the fears of the right came together on this point. Whilst a version of this outcome did eventually come about in St Petersburg and to a lesser extent Berlin, what is perhaps more surprising is the resilience of the capitals under the pressure of their sieges.

Fear of subversion and the internal enemy had serious consequences in persecution of minorities. Germans in St Petersburg, Paris and above all London were subject to discrimination, deportation and occasional mob violence. But even the disgraceful treatment of London's Germans was mild compared to the deportation and murder of many of the leaders of the Armenian community of Constantinople which began on the night of 24 April 1915 as the government tried to secure the city against what it saw as a fifth column that might rise up in support of the allies at the Dardanelles. At the very end of the war there was real concern that a mass deportation of foreigners was planned in order to rehouse the homeless from a serious fire but this never transpired. ${ }^{22}$

The fear of ethnic minorities might have dominated reactions in the first years of the war, but it was the spectre of social revolution that prevailed. In the autumn of 1917 the prospect of organized defeatism was taken very seriously in Paris in the wake of the mutinies in the army. The arrest and subsequent execution of 'Bolo Pasha' paved the way for a political purge that swept away the former ministers Joseph Calliaux and Louis Malvy. The wave of repression in Paris in November 1917 swept up Helene Brion, a pacifist and socialist teacher from the suburb of Pantin. She spent four months in St Lazare prison awaiting trial for 'defeatism' and was debarred from teaching and given a suspended sentence in March 1918. But despite the panic and repression it is hard to argue that Paris really faced a serious organized threat. In the immediate post-war period it has been argued that the local political struggles of the working class in the suburbs did feed in to a wider 'global' revolutionary moment, but is should also be noted that relative to the revolutionary history of the city it was a fairly muted moment. ${ }^{23}$ Petersburg was of course another matter entirely. The decision by the German high command to assist the return of Lenin and other Bolshevik leaders in the hope of undermining the Russian war effort is well known. Actually, the Bolsheviks took some time in 1917 to conclusively position themselves once and for all as 'revolutionary defeatists' despite the apparent consistency of Lenin's insistence that socialists should treat their own government as the principle enemy. In the end the commitment to seeking immediate peace rather than the alternative of revolutionary war was driven 
at least as much by the militant grass roots responding to general war weariness in St Petersburg and elsewhere as it was to any consistent ideological commitment.

Similarly in Berlin and Vienna, it was more the case that militant politicians were able to ride a wave of popular war weariness. It was really only after mutinying sailors from the German High Seas fleet arrived in Berlin that the city can be seriously considered to have entered a revolutionary phase. Constantinople was somewhat different - in that case the war ended with revolution from above as the new Sultan dismissed the CUP (Young Turk) ruling triumvirate on 14 October 1918.

London was undoubtedly the least politically turbulent of the capitals. Even within the United Kingdom the major focal points of political discontent were generally remote from the capital, Clydeside and the Rhondda Valley. In the industrial discontent of 1917-1918 London was largely quiet until the police strike of 1918. Perhaps the most significant political protest movement in London came from the right, where a series of independent 'patriotic' candidates did comparatively well in the last year of the war. Even in their wildest fantasies the enthusiasts of the revolutionary left could not see London as fertile territory.

So what do comparative perspectives tell us about London? London's size and dependence on global trade looked like vulnerabilities in 1914 whilst its distance from the likely front lines was a clear advantage. The economic crisis and the near melt down of the City of London at the start of the war appeared to confirm the weakness, but what is perhaps surprising is the speed with which London recovered and adapted. London's sheer size turned into an asset as well as a vulnerability: it was easy for air attackers to find the capital, but hard to deliver a conclusive blow to a city that was so big. London's global position was in the end an asset in guaranteeing food supplies as the German U-boat campaign never really came close to reducing food imports to critical levels and ironically the long agricultural depression had left a lot of potential for boosting British domestic food production. The same assets would apply in a similar way in 1940-1941.

The story of London's war is generally a more subtle one than that of these other cities. There is perhaps more continuity and less upheaval. But the war did make a permanent impression on the lives of many Londoners which would echo for generations. Stories of the destruction of a Zeppelin lighting the night sky like day and of the explosion at Silvertown breaking windows miles away, of the sound of the guns in Flanders being heard in the park, of wounded soldiers being hurried through the stations, of munitionettes turning canary yellow and of heartbroken leave takings and relieved reuniting embedded themselves in familial memory. Perhaps above all the capital of empire became the pre-eminent landscape for the enactment of the empire's collective memory through the ceremonies at the Cenotaph and the Tomb of the Unknown Warrior. ${ }^{24}$ Symbolically the war was and remains a watershed.

$\underline{\text { Bio. }}$

Adrian Gregory is an Associated Professor at Oxford and Fellow of Pembroke College. He is the author of The Last Great War (Cambridge, 2008) and A War of Peoples (Oxford 2014).

\begin{abstract}
$\underline{\text { Abstract }}$
London was one of six large imperial capitals in Europe which became focal points of total war. In some respects each of these capitals can be understood as undergoing a form of siege in which the endurance of the population at the heart of the combatant Empires was severely tested. London proved to have important resources which helped it to endure better than some of the others.
\end{abstract}

\title{
$\underline{\text { Keywords }}$
}


Bombing, blockade, empires, endurance, mobilization, civil defence

Berlin, Constantiople, London, Paris, St Petersburg, Vienna

${ }^{1}$ See S. Abernethy, 'Moving Wartime London: Public Transport in the First World War', London Journal, 41 (2016), XX$\mathrm{XX}$.

${ }^{2}$ M. B. Barrett, Operation Albion: The German Conquest of the Baltic Islands (Bloomington: Indiana University Press, 2008).

${ }^{3}$ H.G Wells first published The War in the Air in The Pall Mall Gazette in 1908.

${ }^{4}$ A.P. Hyde, The First Blitz: The German Air Campaign against Britain in the First World War (Barnsley: Pen and Sword 2013); N. Hanson, First Blitz: The Secret German Plan to Raze London to the Ground in 1918 (London: Transworld 2010).

${ }^{5}$ S. Grayzel, “'A Promise of Terror to Come": Air Power and the Destruction of Cities in British Imagination and Experience, 1908-39' in S. Goebel and D. Keene (eds.), Cities into Battlefields: Metropolitan Scenarios, Experiences and Commemorations of Total War (Farnham: Ashgate, 2011), 47-62.

${ }^{6}$ See Hanson, First Blitz, 500-30.

${ }^{7}$ O. Nicolajsen and B. Yilmazer, Ottoman Aviation 1911-1920,: <www.ole-nicolajsen.com> [accessed 10 June 2016]; see also Turkey in the First World War, <www.turkeyswar.com/aviation/airdefense.html> [accessed 10 June 2016].

${ }^{8}$ See British Library, 'Raid of Vienna: Major Gabriele D'Annunzio and his Pilot Natale Palli', photograph, $<$ www.bl.uk/collection-items/raid over Vienna> [accessed 10 June 2016]. There is an interesting Italian propaganda film of the raid, Il volo su Vienna, available on Youtube. ".

${ }^{9}<$ Sbiii.com/ordsuper.html\#parisgun> [accessed 10 June 2016]

${ }^{10}$ R.B. McKean, St Petersburg between the Revolutions: Workers and Revolutionaries, June 1907-February 1917 (New Haven: Yale University Press, 1990), 335-44.

${ }^{11}$ Ibid., 345-9.

${ }^{12}$ M. Healy, Vienna and the Fall of the Habsburg Empire: Total War and Everyday Life in World War I (Cambridge: Cambridge Universtiy Press, 2004), 33-5.

${ }^{13}$ Ibid., 39-41, 46-53.

${ }^{14}$ Ibid., 41-2.

${ }^{15}$ B. Davis, Home Fires Burning: Food, Politics and Everyday Life in World War I Berlin (Chapel Hill: University of North Carolina Press, 2000) is highly critical; K. Allen, 'Sharing Scarcity: Bread Rationing and the First World War in Berlin, 1914-1923', Journal of Social History, 32 (1998), 371-93 is more positive but narrower. G.. Yaney, The World of the Manager: Food Administration World War One Berlin (Frankfurt am Main: Peter Lang, 1994) is a nuanced study of one bureaucrat.

${ }^{16}$ C. Rollet, 'The Other War II: Setbacks in Public Health', in J .Winter, J.-L. Robert et al., Capital Cities at War: Paris, London, Berlin 1914-1919, vol. I (Cambridge: Cambridge University Press, 1997), 463

${ }^{17}$ This could be challenged S. Pamuk, 'The Ottoman Economy in World War I', in S. Broadberry and M. Harrison (eds.), The Economics of World War I (Cambridge: Cambridge University Press, 2005), 112-35 paints a damning picture but the severity of rural famine in Syria and Anatolia still seems to be worse.

${ }^{18}$ One of the few useful discussions can be found at Y. Yanikdağ, 'Ottoman Empire/Middle East', 1914-1918 Online: International Encycolpedia of the First World War, <http://encyclopedia.1914-1918online.net/article/ottoman_empiremiddle_east> [accessed 10 June 2016]. 
19 I. Lyster (ed.), Among the Ottomans: Diaries from Turkey in World War I (London: I.B. Tauris, 2010), $24,32$.

${ }^{20}$ R.J. Young (ed.), Under Siege: Portraits of Civilian Life in France during World War I (New York: Berghahn, 2000)

${ }^{21}$ T. Bonzon and B. Davis, 'Feeding the Cities', in Winter, Robert et al., Capital Cities, vol. I, 305-34.

${ }^{22}$ M. Lyster, diary entry for 30 August, in Lyster, Among the Ottomans, 61.

23 T. Stovall, Paris and the Spirit of 1919: Consumer Struggles, Transnationalism, and Revolution (Cambridge: Cambridge University Press, 2012).

${ }^{24}$ A. Gregory, The Silence of Memory: Armistice Day 1919-1946 (Oxford: Berg, 1994) . 